\title{
Myricetin Disturbs the Cell Wall Integrity and Increases the Membrane Permeability of Candida albicans
}

\author{
Heung-Shick Lee' ${ }^{1}$ and Younhee Kim ${ }^{2 *}$ \\ 'Department of Biotechnology and Bioinformatics, Korea University, Sejongsi 30019, Republic of Korea \\ ${ }^{2}$ Department of Korean Medicine, Semyung University, Jecheon 27136, Republic of Korea
}

\begin{abstract}
The fungal cell wall and membrane are the principal targets of antifungals. Herein, we report that myricetin exerts antifungal activity against Candida albicans by damaging the cell wall integrity and notably enhancing the membrane permeability. In the presence of sorbitol, an osmotic protectant, the minimum inhibitory concentration (MIC) of myricetin against C. albicans increased from 20 to 40 and $80 \mu \mathrm{g} / \mathrm{ml}$ in 24 and $72 \mathrm{~h}$, respectively, demonstrating that myricetin disturbs the cell wall integrity of $C$. albicans. Fluorescence microscopic images showed the presence of propidium iodidestained C. albicans cells, indicating the myricetin-induced initial damage of the cell membrane. The effects of myricetin on the membrane permeability of $C$. albicans cells were assessed using crystal violet-uptake and intracellular material-leakage assays. The percentage uptakes of crystal violet for myricetin-treated C. albicans cells at $1 \times, 2 \times$, and $4 \times$ the MIC of myricetin were $36.5,60.6$, and $79.4 \%$, respectively, while those for DMSO-treated C. albicans cells were 28.2, 28.9, and $29.7 \%$, respectively. Additionally, myricetin-treated C. albicans cells showed notable DNA and protein leakage, compared with the DMSO-treated controls. Furthermore, treatment of $C$. albicans cells with $1 \times$ the MIC of myricetin showed a $\mathbf{1 7 . 2}$ and $\mathbf{2 8 . 0 \%}$ reduction in the binding of the lipophilic probes diphenylhexatriene and Nile red, respectively, indicating that myricetin alters the lipid components or order in the $C$. albicans cell membrane, leading to increased membrane permeability. Therefore, these data will provide insights into the pharmacological worth of myricetin as a prospective antifungal for treating C. albicans infections.
\end{abstract}

Keywords: Antifungal, Candida albicans, crystal violet, leakage, membrane permeability, myricetin

Received: October 12, 2021 Accepted: October 28, 2021

First published online: October 30, 2021

*Corresponding author Phone: +82-43-649-1346 Fax: +82-43-649-1341 E-mail:ykim@semyung.ac.kr

pISSN 1017-7825 elSSN 1738-8872

Copyright $@ 2022$ by the authors. Licensee KMB. This article is a open access article distributed under the terms and condition of the Creative Commons Attribution (CC BY) license.

\section{Introduction}

Candida albicans is the leading fungal species causing nosocomial infections [1]; however, a noticeable shift towards non-albicans species of Candida, including C. tropicalis, followed by C. glabrata and C. krusei, has been reported [2]. C. albicans is a commensal that is present in 15-60\% of symptomless individuals in the yeast form and commonly demonstrates yeast-to-hypha transitions along with tissue infiltration and infection [3]. In recent times, the incidence of lethal systemic candidiasis has increased dramatically on account of the increase in the numbers of seriously ill or immunocompromised patients, such as transplant recipients, patients with cancer and HIV infections, and patients showing the frequent use of invasive medical treatment [4]. Virulence factors of C. albicans contribute towards the pathogenesis of infections caused by this fungus; such virulence factors include adhesin molecules for host recognition, ability of morphogenesis between unicellular yeast cells and filamentous forms, and secretion of aspartyl proteases and phospholipases [5]. Additionally, the biofilm formation ability of Candida spp. is known to be implicated in the increased resistance to antifungal therapies and the host immune system [6].

The main targets of available antifungal drugs for the treatment of systemic fungal infections can be categorized as follows: the fungal cell membrane, cell wall, and nucleic acids. Inhibition of lanosterol $14 \alpha$-demethylase by azoles causes the exhaustion of ergosterol, an analog of cholesterol, in the fungal cell membrane, and accumulation of sterol precursors, leading to alterations in the structure and function of the plasma membrane $[7,8]$. Polyenes such as amphotericin B bind to and extract ergosterol directly, resulting in the disruption of many components of the yeast cell physiology $[9,10]$. Furthermore, the interaction of amphotericin B with sterol causes membrane permeabilization via the production of ion channel formation, leading to the leakage of $\mathrm{K}^{+}$and $\mathrm{Na}^{+}$and the death of yeast cells [10]. Echinocandins are inhibitors of $(1,3)-\beta$-glucan synthase, a large integral membrane heterodimeric protein in the biosynthetic pathway of $(1,3)$ - $\beta$-glucan, which is a major component of the fungal cell wall $[11,12]$. Nucleotide analogs, including 5 -fluorocytosine, inhibit nucleic acid synthesis [13].

Although extensive studies have been performed to explore new antifungal drugs, commonly available drugs 
for the treatment of candidiasis are rather limited due to the eukaryotic nature of fungi and the emergence of drugresistant yeast strains resulting from the common and prolonged use of antifungals $[14,15]$. Therefore, it is essential to explore novel antifungals that are both safe to use and effective against Candida infections. There has been a long history of people using natural products to cure diseases and ailments. The advantages of plantderived products used in food or traditional medicine include their effectiveness against microbes or insects and relatively high safety, given their repeated use or application for centuries. Myricetin is a common plant-derived product; it is a member of the flavonoid class that is found commonly in berries, red wines, teas, and vegetables [16]. Myricetin is produced by plants from a variety of families, including Myricaceae [17], Anacardiaceae [18], Polygonaceae [19], and Primulaceae [20]; it possesses many pharmacological activities, including antioxidant [21], anticancer [22], antidiabetic [16], anti-inflammatory [23], analgesic [24], antifungal [25], and hepatoprotective properties [26]. Moreover, myricetin has been used to preserve foods containing oils and fats due to its ability to protect lipids against oxidation [16].

The present study illustrates that myricetin has antifungal activity against pathologically important Candida species including C. albicans, C. glabrata, C. krusei, and C. parapsilosis. The mechanism underlying the antifungal action of myricetin was evaluated against $C$. albicans, a major fungal pathogen, with a focus on cell wall integrity using the sorbitol protection assay, and cell membrane permeability using propidum iodide(PI)-staining, crystal violet uptake, intracellular material leakage, diphenylhexatriene (DPH)-binding, and Nile red-binding analyses.

\section{Materials and Methods}

Candida Strains and Growth Conditions

The C. albicans SC5314 (ATCC MYA-2876) and C. parapsilosis ATCC 22019 were purchased from the American Type Culture Collection (ATCC, USA), and C. glabrata ATCC 2001 (KCCM 50044, CBS 138) and C. krusei ATCC 6258 (KCCM 11426) were procured from the Korean Culture Center of Microorganisms (KCCM, Korea), respectively. C. albicans SC5314 was used for routine analysis and other strains were included as controls. Routine cultures were carried at $35^{\circ} \mathrm{C}$ in yeast mold (YM) broth (Difco, USA).

\section{Reagents}

Myricetin was obtained commercially from Tauto Biotech (China). DMSO (Dimethyl Sulfoxide), amphotericin B, Calcofluor White (CFW) M2R, PI, crystal violet, DPH and Nile red were purchased from Sigma (USA). Phosphate Buffered Saline (PBS, pH 7.4) was procured from Gibco (USA) and Qubit dsDNA BR kit was purchased from Invitrogen (USA). Bradford reagent was obtained from Bio-Rad (USA). In addition, myricetin $(20 \mathrm{mg} / \mathrm{ml})$ was dissolved in DMSO, aliquoted, and stored at $-20^{\circ} \mathrm{C}$ in the dark until use. Crystal violet $(0.1 \mathrm{mg} / \mathrm{ml})$ was dissolved in water, filtered, and stored at $-20^{\circ} \mathrm{C}$. Nile red $(1 \mathrm{mg} / \mathrm{ml})$ was dissolved in acetone and stored at $4^{\circ} \mathrm{C}$.

\section{Antifungal Susceptibility Testing}

Antifungal susceptibility to myricetin was evaluated for each strain by the standard broth microdilution CLSI M27-A3 method [27], using resazurin as a cell growth indicator [28].

Briefly, the two-fold serial dilutions of myricetin or amphotericin B $(100 \mu \mathrm{l})$ were added to the wells of a roundbottom 96-well microplate containing RPMI-1640 medium. The inoculum suspension (100 $\mu \mathrm{l})$ containing $0.1 \mathrm{mg} / \mathrm{ml}$ resazurin was added to attain a final cell density of $1 \times 10^{3}-5 \times 10^{3}$ cells $/ \mathrm{ml}$, and the plate was incubated at $35^{\circ} \mathrm{C}$ for $24 \mathrm{~h}$. Colorimetric MIC end-points were considered as the lowest sample concentration at which the solution remained blue, or the first sample whose color changed from blue to purple [28]. DMSO, which was the solvent used for the preparation of myricetin solution, was included as a growth control; no growth-inhibitory effects of DMSO were detected up to the concentration of $1 \%$. Amphotericin B was used as a positive control.

\section{Sorbitol Protection Assay}

To ascertain whether myricetin affects the C. albicans cell wall structure, the sorbitol protection assay [29] was performed using modified CLSI M27-A3 protocol, with resazurin [30]. In a 96-well round bottom microplate, two-fold dilutions of myricetin and two-fold dilutions of myricetin with $0.8 \mathrm{M}$ sorbitol were added in two separate rows. All the wells were inoculated with $C$. albicans cell suspensions, and the plate was incubated at $35^{\circ} \mathrm{C}$. The MIC values were evaluated at the 24 - and 72 -h time points.

\section{Microscopic Analysis}

To examine the effect of myricetin on C. albicans cells, the myricetin-treated cells were observed using a confocal laser scanning microscope (CLSM) and a fluorescence microscope, respectively. First, log-phase C. albicans cells $1 \times 10^{8}$ cells $/ \mathrm{ml}$ were grown in the presence of $20 \mu \mathrm{g} / \mathrm{ml}$ myricetin or $1 \mu \mathrm{g} / \mathrm{ml}$ amphotericin B in YM broth at $35^{\circ} \mathrm{C}$ with agitation at $200 \mathrm{rpm}$. The cells were harvested either at 2.5 or $4 \mathrm{~h}$ by centrifugation at $12,000 \times g$ for $1 \mathrm{~min}$ and stained with $10 \mu \mathrm{g} / \mathrm{ml}$ PI in PBS. The cells were observed using a CLSM. Secondly, C. albicans SC5314 cells $\left(1 \times 10^{8}\right.$ cells) were grown in the presence of $2 \mu \mathrm{l}$ of DMSO or $40 \mu \mathrm{g}$ myricetin per $\mathrm{ml}$ of YM broth at $35^{\circ} \mathrm{C}$ with shaking at $200 \mathrm{rpm}$ for $2.5 \mathrm{~h}$. The cells were harvested by centrifugation at 12,000 $\times g$ for $1 \mathrm{~min}$ and stained with $10 \mu \mathrm{g} / \mathrm{ml}$ PI and $0.01 \%$ CFW in PBS. Then, they were observed using a fluorescence microscope equipped with triple RGB filters or a bright-field microscope.

\section{Crystal Violet-Uptake Assay}

To evaluate the effects of myricetin on membrane permeability, the crystal violet-uptake assay was performed according to the method described by Vaara and Vaara [31] with slight modifications. Log-phase C. albicans 
SC5314 cells were harvested by centrifugation at $12,000 \times g$ for $5 \mathrm{~min}$, and then washed and resuspended in PBS. Cell suspensions $\left(5 \times 10^{7} \mathrm{cells} / \mathrm{ml}\right)$ were treated with $1 \times, 2 \times$, or $4 \times$ the $\mathrm{MIC}$ of myricetin and incubated at $35^{\circ} \mathrm{C}$ with shaking at $200 \mathrm{rpm}$ for 30 and $60 \mathrm{~min}$. Solvent (DMSO) controls for each treatment of myricetin were included. Then, the cell suspensions $(0.9 \mathrm{ml})$ were harvested by centrifugation at $12,000 \times g$ for $5 \mathrm{~min}$ and washed in PBS. The cells were suspended in $1 \mathrm{ml}$ of PBS containing $10 \mu \mathrm{g} / \mathrm{ml}$ crystal violet and incubated at $35^{\circ} \mathrm{C}$ with shaking at $200 \mathrm{rpm}$ for $15 \mathrm{~min}$. Further, the cells were precipitated by centrifugation at $12,000 \times g$ and $4^{\circ} \mathrm{C}$ for $20 \mathrm{~min}$, and the supernatant $(0.2 \mathrm{ml})$ was placed in quadruplicate into a 96-well flat-bottom microplate. The amount of crystal violet remaining in the supernatant was measured as the absorbance at $590 \mathrm{~nm}\left(\mathrm{~A}_{590}\right)$ using a spectrofluorometer (Tecan, Austria). The optical density values of the initial solution of crystal violet used in the assay were regarded as $100 \%$. The percentage of crystal violet uptake was calculated using the following formula: uptake of crystal violet $(\%)=1-\mathrm{A}_{590}$ of the sample/ $\mathrm{A}_{590}$ of crystal violet solution $\times 100$.

\section{Leakage of Intracellular Materials}

An evaluation of myricetin-induced nucleotide and protein leakage was performed using a fluorometric and spectrophotometric method, respectively [32]. An overnight culture of C. albicans SC5314 cells was diluted by 1:5 into fresh YM broth and incubated further at $35^{\circ} \mathrm{C}$ with shaking at $200 \mathrm{rpm}$ for $3 \mathrm{~h}$. The cells were harvested by centrifugation at $12,000 \times g$ for $5 \mathrm{~min}$, washed with PBS, and resuspended in PBS to achieve a cell density of $1 \times 10^{8}$ cells $/ \mathrm{ml}$. The cell suspensions were then incubated with 40 and $80 \mu \mathrm{g} / \mathrm{ml}$ myricetin at $35^{\circ} \mathrm{C}$ with agitation at $200 \mathrm{rpm}$ for 30 or $60 \mathrm{~min}$. DMSO controls for each myricetin treatment were included. The cell suspensions $(0.8 \mathrm{ml})$ were centrifuged at $13,200 \times g$ at $4^{\circ} \mathrm{C}$ for $20 \mathrm{~min}$, and the supernatants were saved for further analysis. For the nucleotide leakage analysis, the Qubit dsDNA BR assay kit and a Qubit 4 Fluorometer was used; this kit measures the levels of double-stranded DNA over RNA highly selectively. The supernatant $(20 \mu \mathrm{l})$ were mixed with $180 \mu \mathrm{l}$ of working solution in triplicate and the fluorescence of these mixtures was measured. The concentrations of the nucleotides in the samples were calculated using the dilution calculator feature of the Qubit 4 fluorometer. For protein leakage analysis, the Bradford assay [33] was performed according to the manufacturer's instructions. Diluted Bradford concentrate $(150 \mu \mathrm{l})$ mixed with $50 \mu \mathrm{l}$ of supernatant or PBS was added to a 96-well clear flat-bottom microplate in quadruplicate, and the absorbance of the samples at $590 \mathrm{~nm}$ was measured using a spectrofluorometer. The amount of protein leakage was calculated as the $\mathrm{A}_{590}$ of the sample - the $\mathrm{A}_{590}$ of Bradford solution containing PBS.

\section{DPH-Binding Assay}

To monitor whether myricetin affects the lipid components or order in the C. albicans cell membrane, the DPHbinding assay was performed [32]. C. albicans SC5314 cells $\left(1 \times 10^{8} \mathrm{cell} / \mathrm{s} / \mathrm{ml}\right)$ at the log phase were incubated with myricetin or DMSO at $35^{\circ} \mathrm{C}$ with shaking at $200 \mathrm{rpm}$ for $30 \mathrm{~min}$. The cells $(0.9 \mathrm{ml})$ were then harvested by centrifugation at $12,000 \times g$ for $5 \mathrm{~min}$, washed with PBS, and resuspended in $0.9 \mathrm{ml}$ of PBS containing $50 \mu \mathrm{M} \mathrm{DPH}$. The cell suspension $(0.2 \mathrm{ml})$ was then transferred in quadruplicate to a 96 -well black flat-bottom microplate, followed by incubation for $10 \mathrm{~min}$ in the dark at room temperature. The amount of DPH binding to the C. albicans cell membrane was measured using a spectrofluorometer (Tecan, Austria) at $360 \mathrm{~nm}$ (bandwidth, $35 \mathrm{~nm}$ ) and $460 \mathrm{~nm}$ (bandwidth, $10 \mathrm{~nm}$ ) as the excitation and emission wavelengths, respectively. The DPH-binding percentage was calculated using the following formula: relative DPH binding $(\%)=\left(\mathrm{F}_{\text {myricetin }}-\mathrm{F}_{\mathrm{PBS} \text { containing DPH }}\right) /$ $\left(\mathrm{F}_{\mathrm{DMSO} \text { control }}-\mathrm{F}_{\mathrm{PBS} \text { containing DPH }}\right) \times 100 ; \mathrm{F}$ represents the fluorescence intensity.

\section{Nile Red-Binding Assay}

The Nile red-binding assay was performed as follows: C. albicans SC5314 cells in the exponential growth phase were harvested by centrifugation at $12,000 \times g$ and the precipitate was suspended in PBS. The cell suspension $(2 \times$ $10^{7}$ cells $/ \mathrm{ml}$ ) was exposed to myricetin (from 20 to $80 \mu \mathrm{g} / \mathrm{ml}$ ) or an equivalent amount of DMSO at $35^{\circ} \mathrm{C}$ with agitation at $200 \mathrm{rpm}$ for $1 \mathrm{~h}$. Then, the cells $(0.9 \mathrm{ml})$ were harvested by centrifugation at 12,000 $\times g$ for $15 \mathrm{~min}$, washed with PBS, and suspended in $0.9 \mathrm{ml}$ of PBS containing $0.25 \mathrm{mg} / \mathrm{ml}$ Nile red solution. The cell suspension $(0.2 \mathrm{ml})$ was transferred in quadruplicate to a 96-well black flat-bottom microplate, followed by incubation for $5 \mathrm{~min}$ in the dark at room temperature. The amount of Nile red binding to C. albicans cells was measured using a spectrofluorometer at $488 \mathrm{~nm}$ (with a bandwidth of $20 \mathrm{~nm}$ ) and $580 \mathrm{~nm}$ (with a bandwidth of $20 \mathrm{~nm}$ ) as the excitation and emission wavelengths, respectively. The Nile red-binding percentage was calculated using the following formula: relative Nile red binding $(\%)=\left(\mathrm{F}_{\text {myricetin }}-\mathrm{F}_{\mathrm{PBS} \text { containing Nile red }}\right) /\left(\mathrm{F}_{\mathrm{DMSO} \text { control }}-\mathrm{F}_{\mathrm{PBS} \text { containing Nile red }}\right) \times$ 100 ; F represents the fluorescence intensity.

\section{Statistical Analysis}

All experiments were performed at least twice in triplicate or quadruplicate. For each outcome, the data were represented as mean \pm standard deviation. The effect of myricetin compared with controls was analyzed using SigmaPlot 13.0. A $p$ value less than 0.05 was regarded as statistically significant.

\section{Results and Discussion}

\section{Antifungal Susceptibility Testing}

Higher plants defend against pathogens with secondary metabolites or antimicrobial compounds including polyphenols, such as myricetin. The MIC of myricetin against C. albicans SC5314, a strain used for routine assays in several fungus-related studies, was $20 \mu \mathrm{g} / \mathrm{ml}$. The MIC values of myricetin against C. glabrata ATCC 2001, C. krusei ATCC 6258, and C. parapsilosis ATCC 22019 were 1.3, 5, and $5 \mu \mathrm{g} / \mathrm{ml}$, respectively (Table 1). In contrast, 
Table 1. MICs of myricetin against Candida spp.

\begin{tabular}{lcc}
\hline & \multicolumn{2}{c}{ MIC $(\mu \mathrm{g} / \mathrm{ml})$} \\
\cline { 2 - 3 } & Myricetin & Amphotericin B \\
\hline C. albicans SC5314 (ATCC MYA-2876) & 20 & 1 \\
C. glabrata ATCC 2001 (KCCM 50044) & 1.3 & 1 \\
C. krusei ATCC 6258 (KCCM 11426) & 5 & 0.5 \\
C. parapsilosis ATCC 22019 & 5 & 1 \\
\hline
\end{tabular}

The in vitro MICs of myricetin against Candida spp. were determined by the modified CLSI M27-A3 method containing resazurin

Table 2. Sorbitol protection assay and MICs of myricetin against C. albicans SC5314.

\begin{tabular}{cccccc}
\hline & \multicolumn{5}{c}{ MIC $(\mu \mathrm{g} / \mathrm{ml})$} \\
\cline { 2 - 5 } & RPMI & $24 \mathrm{~h}$ & RPMI + sorbitol & RPMI & RPMI + sorbitol \\
\cline { 2 - 5 } & 20 & 40 & 20 & 80 \\
\hline
\end{tabular}

Antifungal susceptibility tests were performed by the modified CLSI M27-A3 protocol containing resazurin without or with $0.8 \mathrm{M}$ sorbitol, and MICs were determined after 24 and $72 \mathrm{~h}$, respectively.

the MIC values of amphotericin B against the tested Candida species ranged from 0.5 to $1 \mu \mathrm{g} / \mathrm{ml}$. Myricetin appears to have moderate anticandidal activity and the data agree reasonably with other researcher's MIC values of $16-64 \mu \mathrm{g} / \mathrm{ml}$ against C. albicans, $3.9 \mu \mathrm{g} / \mathrm{ml}$ against C. glabrata, $64 \mu \mathrm{g} / \mathrm{ml}$ against $C$. $k r u s e i$, and $54 \mu \mathrm{g} / \mathrm{ml}$ against C. tropicalis [25]. The reason why the MIC value of myricetin is considerably higher $(20 \mu \mathrm{g} / \mathrm{ml})$ than that of amphotericin B $(1 \mu \mathrm{g} / \mathrm{ml})$ against C. albicans SC5314 is due to their differences in cellular targets and structures, although both amphotericin B and myricetin induce increased membrane permeability to result in cell death.

\section{Sorbitol Protection Assay}

The fungal cell wall surrounding cell membrane affords cells strength and rigidity and maintains osmotic support from the turgor pressure of protoplasts. Impairments in cell wall components by antifungals will result in cell lysis, but cells can survive in the presence of an appropriate osmotic protectant in the medium [29]. To examine whether the antifungal activity of myricetin is related to the alteration of the fungal cell wall structure, the sorbitol protection assay was performed using the CLSI M27-A3 microdilution assay with myricetin against C. albicans cells with or without $0.8 \mathrm{M}$ sorbitol (Table 2). In the presence of sorbitol, the MIC values of myricetin against C. albicans increased from 20 to 40 and $80 \mu \mathrm{g} / \mathrm{ml}$ in 24 and $72 \mathrm{~h}$, respectively. The increase in the MIC values in the sorbitol protection assay indicates that myricetin is involved in disrupting the integrity of the C. albicans cell wall.

\section{Microscopic Analysis}

PI can bind to DNA and RNA through compromised cell membranes, but it is mostly eliminated from live cells. Therefore, PI can enter dead or dying cells with defective cell membranes and emit a red fluorescence signal, while live cells with intact cell membranes are not stained with PI [34]. As can be seen in Fig. 1B2, CLSM images show the presence of red PI-stained myricetin-treated C. albicans cells, suggesting that the $C$. albicans cells showed an initial impairment of the cell membrane after treatment with $20 \mu \mathrm{g} / \mathrm{ml}$ myricetin for $2.5 \mathrm{~h}$. Although cell lysis was not detectable in the cells treated with myricetin for $2.5 \mathrm{~h}$, they were noticeable after myricetin treatment for $4 \mathrm{~h}$, as indicated by arrows in Fig. 1C3. Amphotericin B-treated C. albicans cells, the positive controls, were seen as fluorescent red cells with an intact form (cell wall), indicating that amphotericin B is involved in damaging the C. albicans cell membrane (Fig. 1D2). Amphotericin B, which is a polyene macrolide, is reported to participate in the formation of protein-like ion channels in the cell membrane $[35,36]$ or the disruption of the polar head group region of biomembranes [37]. Lysed cell debris (Fig. 1C3), a characteristic of cells with a damaged cell wall, is easily found in myricetin-treated C. albicans cells. Thus, the results of the sorbitol protection assay and confocal laser microscopic analysis demonstrated that myricetin disrupts the cell wall integrity and injures the C. albicans cell membrane.

In addition, C. albicans cells treated with DMSO or $40 \mu \mathrm{g} / \mathrm{ml}$ myricetin for $2.5 \mathrm{~h}$ were stained with both CFW and PI. CFW is a fluorescent dye that stains fungal cell walls, which are composed of cellulose, chitin, and other $\beta$ 1,4-carbohydrates [38]. As seen in Fig. 2C, the control C. albicans cells showed fluorescent blue cell walls stained with CFW, and no significant red fluorescence was detected, demonstrating that the cells had intact cell walls and membranes. In contrast, red fluorescent aggregates were found in case of myricetin-treated C. albicans cells (Fig. 2D). Furthermore, these PI-stained cells looked atrophied and formed cell aggregates, as indicated by red arrows in a bright-field image (Fig. 2B). These aggregates or clumps were generally detected when C. albicans cells were exposed to relatively high myricetin concentrations, such as $2 \times$ or $4 \times$ the MIC of myricetin, or sublethal concentrations of myricetin for a long time $(>4 \mathrm{~h})$. We assume that large membranous clumps and cell aggregates may be formed by membrane fusion and ionic interactions between protoplasts, respectively, in case of myricetintreated C. albicans cells because they have a compromised cell wall. 


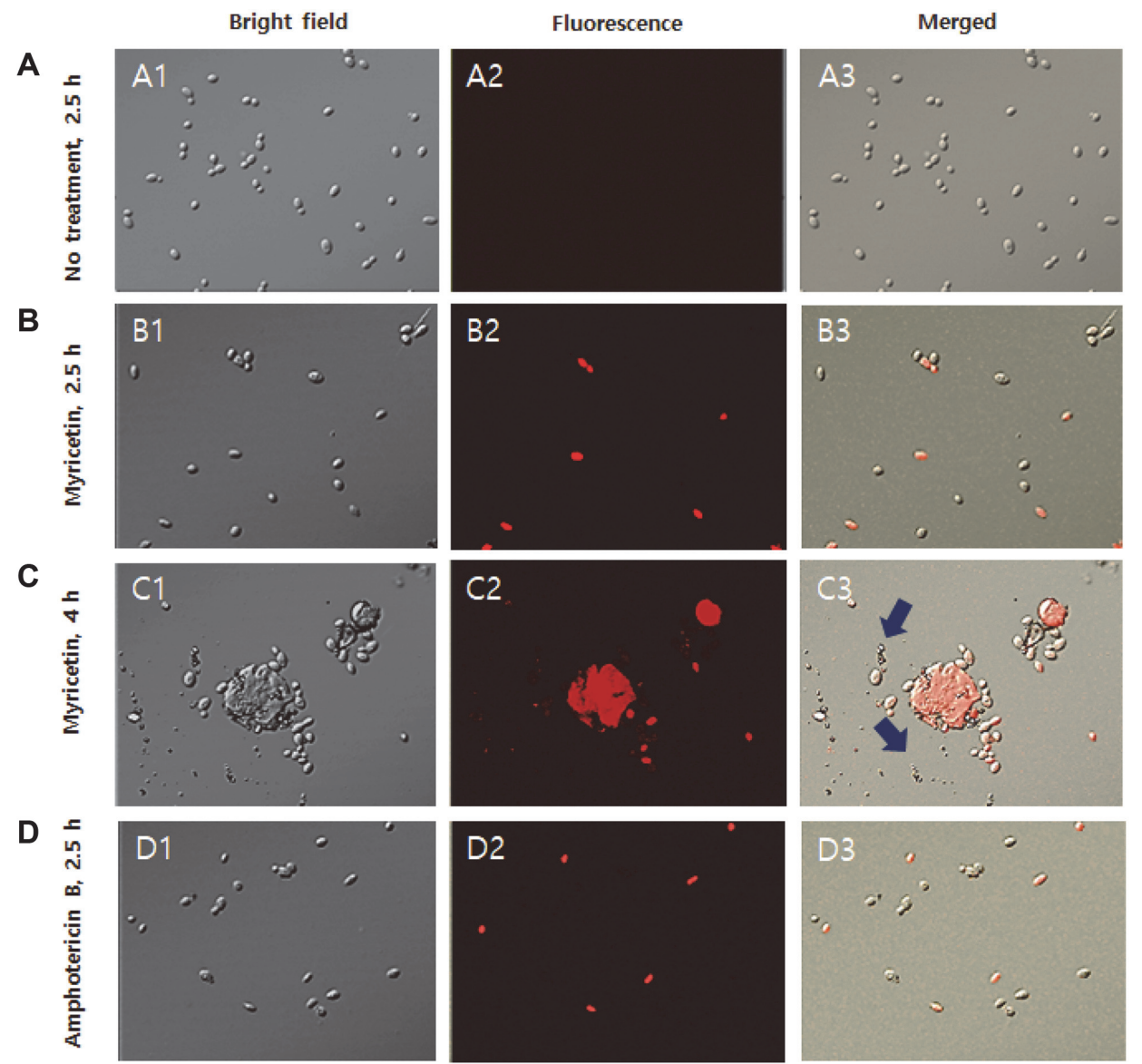

Fig. 1. Confocal laser microscopic images of C. albicans SC5314 cells. C. albicans cells were incubated with DMSO (A1, A2, and A2) for $2.5 \mathrm{~h}, 20 \mu \mathrm{g} / \mathrm{ml}$ myricetin for $2.5 \mathrm{~h}(\mathrm{~B} 1, \mathrm{~B} 2$, and B3) and $4 \mathrm{~h}(\mathrm{C} 1, \mathrm{C} 2$, and C3), or $1 \mu \mathrm{g} / \mathrm{ml}$ amphotericin B for $2.5 \mathrm{~h}(\mathrm{D} 1, \mathrm{D} 2$, and D3). The cells were stained with $10 \mu \mathrm{g} / \mathrm{ml} \mathrm{PI}$.
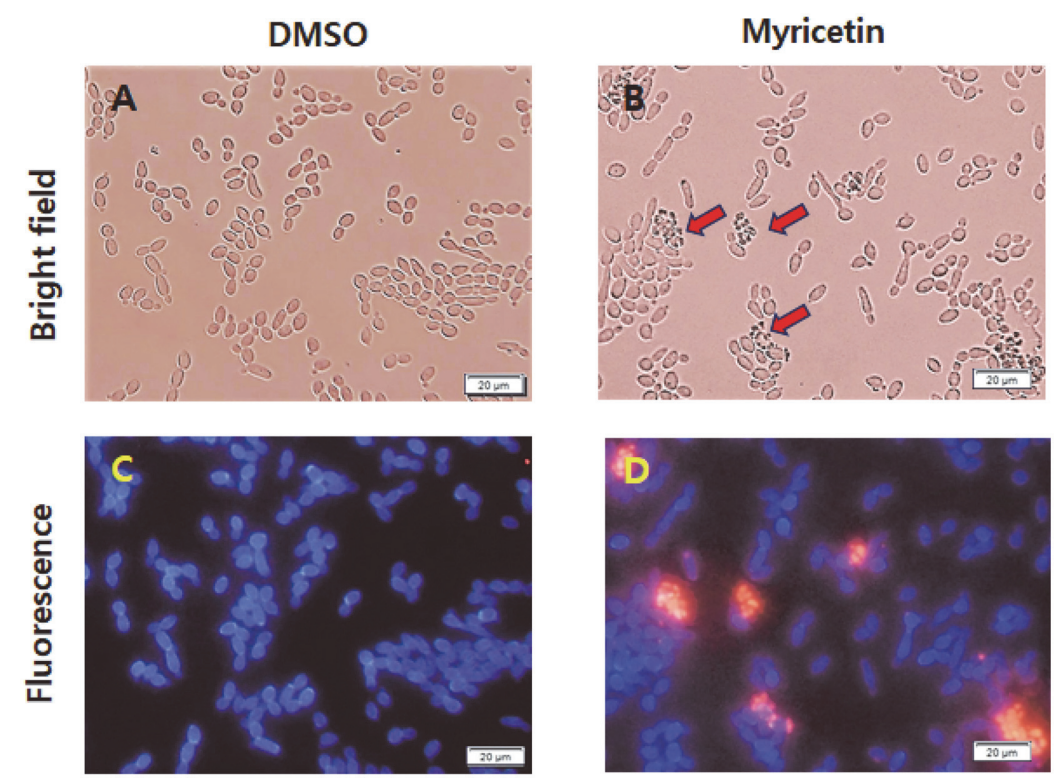

Fig. 2. Microscopic images of C. albicans SC5314 cells. C. albicans cells were incubated with DMSO (A and C) or $40 \mu \mathrm{g} / \mathrm{ml} \mathrm{myricetin}$ (B and D) and double-stained with $10 \mu \mathrm{g} / \mathrm{ml}$ PI and $0.01 \%$ CFW. Bright-field (A and B) and fluorescence (C and D) images of the cells are shown. The C. albicans cell walls were stained blue with CFW (C and D) and the cells with injured membranes were stained red with PI (D). Scale bars: $20 \mu \mathrm{m}$. 
A

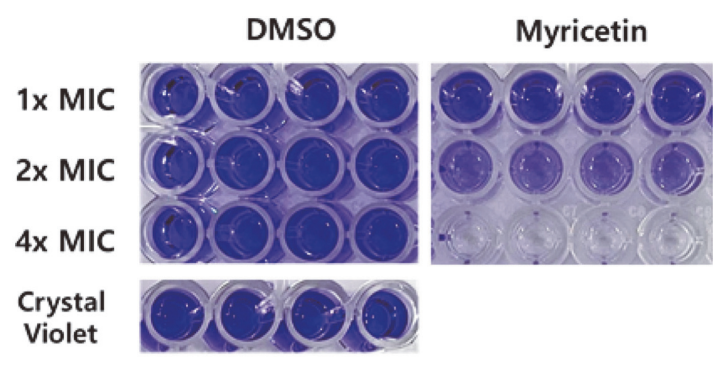

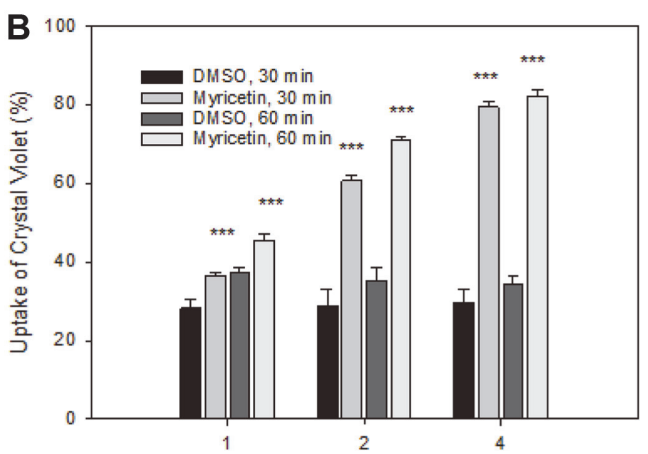

Treatment $(x$ MIC)

Fig. 3. Crystal violet-uptake assay. (A) C. albicans cells treated with myricetin or DMSO for 30 min were harvested, suspended in crystal violet solution, and incubated further for $15 \mathrm{~min}$. The cells were precipitated by centrifugation and the supernatant was placed into a 96-well flat-bottom microplate, as shown. (B) The amount of crystal violet in the supernatant was measured as the absorbance at $590 \mathrm{~nm}$. The relative uptake of crystal violet (\%) of myricetin- or DMSO-treated C. albicans cells is presented as the mean \pm standard deviation. Representative data from one of three independent experiments is shown. ${ }^{* * *} p<$ 0.001: DMSO control vs myricetin-treated sample.

\section{Crystal Violet-Uptake Assay}

Crystal violet or gentian violet exists as a lipophilic cation at neutral pHs. Although it does not penetrate cells with intact cell membranes, crystal violet enters cells with damaged cell membranes. Hence, the crystal violetuptake assay is generally used for the detection of membrane impairment. As myricetin-treated C. albicans cells were seen as PI-stained fluorescent red cells, these were identified as membrane-damaged cells (Figs. 1 and 2). Therefore, the crystal violet-uptake assay was performed to ascertain whether myricetin affects the membrane permeability of $C$. albicans cells.

C. albicans cells treated with $1 \times, 2 \times$, and $4 \times$ the MIC of myricetin or an equivalent amount of DMSO for 30 min were subjected to the crystal violet-uptake assay; the cell supernatants were placed in a 96-well microplate, as shown in Fig. 3A. There was a notable difference in color between the supernatants of cells treated with each concentration of myricetin supernatant and the supernatants of those treated with equivalent amounts of DMSO (control); this difference was concentration-dependent (Fig. 3A). The percentages of crystal violet uptake by C. albicans cells treated with $1 \times, 2 \times$, and $4 \times$ the MIC of myricetin for 30 min were $36.5,60.6$, and $79.4 \%$, while those by C. albicans cells treated with the corresponding amounts of DMSO were 28.2, 28.9, and 29.7\%, respectively (Fig. 3B). The difference between each myricetin-treated sample and an equivalent DMSO control was statistically significant $(p<0.001)$, and these data clearly demonstrate that myricetin markedly increases the membrane permeability of $C$. albicans cells.

\section{Leakage of Intracellular Materials}

Since the notable enhancement of the membrane permeability in myricetin-treated C. albicans cells was displayed via the crystal violet-uptake assay, whether the treatment of $C$. albicans cells with myricetin causes the leakage of nucleotides and proteins was examined using the fluorometric and spectrophotometric method, respectively. C. albicans cells treated with DMSO or myricetin for 30 or 60 min were centrifuged and the supernatants were subjected to an analysis of the leakage of intracellular materials. As seen in Fig. 4A, DNA leakage levels of 0.139 and $0.241 \mu \mathrm{g} / \mathrm{ml}$ were found in case of the C. albicans cells treated with $2 \times$ and $4 \times$ the MIC of myricetin for $30 \mathrm{~min}$, respectively, but a negligible amount and $0.104 \mu \mathrm{g} / \mathrm{ml}$ of DNA leakage were detected in the C. albicans cells treated with equivalent amounts of DMSO (0.2 and 0.4\% DMSO), respectively. The difference observed between the DNA leakage levels in the myricetin-treated cells and the corresponding DMSO-treated controls was significant $(p<0.001)$.

For the protein leakage analysis, the $\mathrm{A}_{590}$ was measured after Bradford reagent was mixed with the supernatant (Fig. 4B). The absorbance values at $590 \mathrm{~nm}$ at $30 \mathrm{~min}$ were 0.030 and 0.040 in case of the control cells treated with $2 \times$ and $4 \times$ the MIC of DMSO, respectively, but were 0.218 and 0.281 in case of the C. albicans cells treated with $2 \times$ and $4 \times$ the MIC of myricetin, respectively. The difference between the $\mathrm{A}_{590}$ values of each myricetin-treated cell sample and the corresponding DMSO-treated control cell sample was also significant $(p<0.001)$. As revealed by the results of the crystal violet-uptake assay (Fig. 3) and the analysis of the leakage of intracellular materials (Fig. 4), the antifungal effects of myricetin against the membrane permeability of $C$. albicans cells were remarkable.

\section{The Binding of DPH into C. albicans Cell Membranes}

To keep the viability of $C$. albicans cells, maintaining the integrity of the cell membrane is critical. Cells can regulate membrane function through regulating membrane fluidity and membrane protein arrangement. Therefore, changes in membrane permeability are related to alterations in membrane fluidity, which occur via changes in the lipid composition or order or pore formation. Hence, whether the increase of membrane 

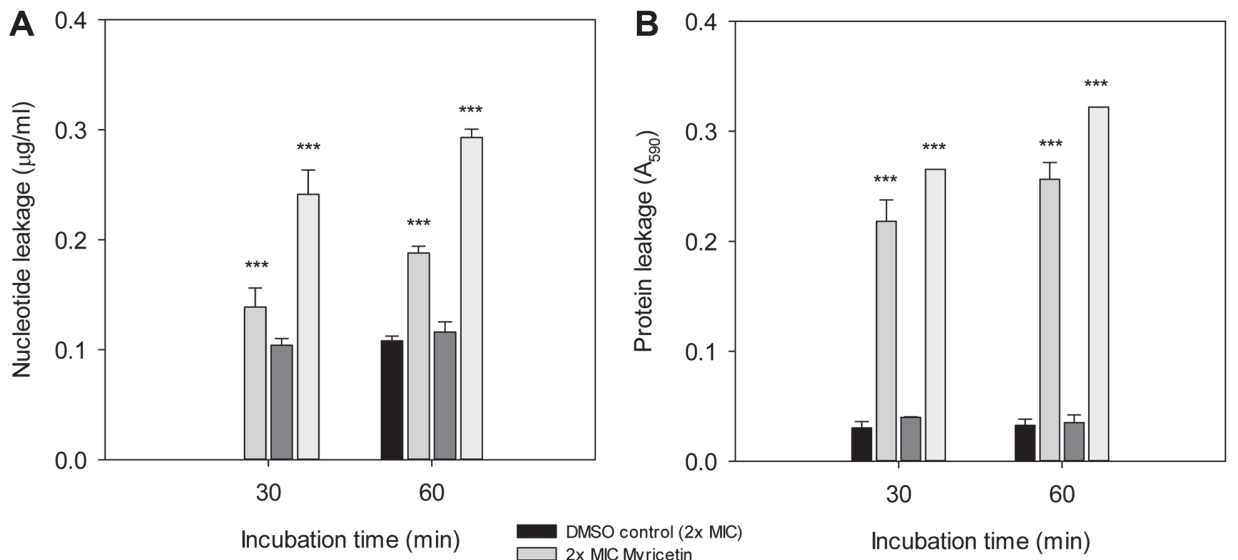

Fig. 4. Nucleotide and protein leakage. C. albicans cells suspended in PBS were incubated with $2 \times$ or $4 \times$ the MIC of myricetin and centrifuged after the indicated time periods. Then, the supernatants were analyzed for nucleotide leakage (A) or for protein leakage (B). The data are shown as the means \pm standard deviations. Representative data from one of three independent experiments are shown. ${ }^{* * *} p<0.001$ : DMSO control vs myricetin-treated sample.

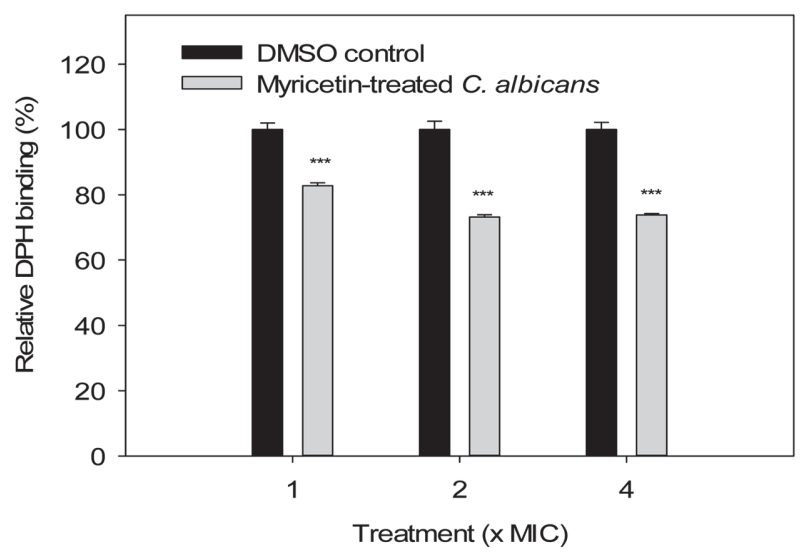

Fig. 5. Entry of DPH into C. albicans cell membranes. Myricetin- or DMSO-treated C. albicans cells were incubated in PBS containing $50 \mu \mathrm{M} \mathrm{DPH}$, and the fluorescence intensity of each sample was measured at $360 \mathrm{~nm}$ (bandwidth, $35 \mathrm{~nm}$ ) and $460 \mathrm{~nm}$ (bandwidth, $10 \mathrm{~nm}$ ) as the excitation and emission wavelengths, respectively. The data represent the means \pm standard deviations obtained from one of three independent experiments. ${ }^{* * *} p<0.001$ : DMSO control vs myricetin-treated sample.

permeability is associated with the lipid composition or order of C. albicans cell membrane was investigated using the DPH- or Nile red-binding assay.

$\mathrm{DPH}$ is almost non-fluorescent in water, but it shows a strong fluorescence after intercalation into membranes. Therefore, it can be used as a probe for viscosity, polarity, and lipid order [39]. DMSO- or myricetin-treated C. albicans cells were incubated with PBS containing DPH, and the fluorescence intensity of each sample was measured. The relative percentages of DPH binding to C. albicans cells treated with $1 \times, 2 \times$, and $4 \times$ the MIC of myricetin for $30 \mathrm{~min}$ were $82.8 \pm 0.9,73.2 \pm 0.7$, and $73.8 \pm 0.5 \%$, respectively, compared to the corresponding DMSO controls (Fig. 5). The difference between each myricetin-treated cell sample and the corresponding DMSO-treated control cells was significant $(p<0.001)$, and there was no significant difference between the DPH binding (\%) of the cells treated with $2 \times$ and $4 \times$ the MIC of myricetin. Consequently, decreased DPH entry into myricetin-treated C. albicans cell membranes suggest that myricetin causes alterations of the lipid components or order of C. albicans cell membranes.

\section{The Binding of Nile Red to C. albicans Cell Membranes}

Nile red is a fluorescent probe that is used as a lipid stain to visualize bacterial cell membranes [40]. This dye displays low fluorescence in a polar environment, but selectively binds to lipids and emits strong fluorescence when incorporated into hydrophobic cell membranes [41, 42]. The penetration depth and the orientation of Nile red may vary in membranes with different lipid compositions; this could affect its fluorescence-emission ratios [43]. Therefore, Nile red can be used for monitoring the organization, fluctuation, and heterogeneity in membranes, specifically for membranes containing cholesterol [41, 44]. Accordingly, it was assumed that the 
Table 3. Nile red-binding assay.

\begin{tabular}{ccccccc}
\hline \multicolumn{3}{c}{ DMSO } & \multicolumn{5}{c}{ Myricetin } & \\
\hline $\begin{array}{c}\text { Treatment } \\
(\%)\end{array}$ & $\begin{array}{c}\text { Fluorescence } \\
(\mathrm{AU})\end{array}$ & $\begin{array}{c}\text { Relative } \\
\text { fluorescence }(\%)\end{array}$ & $\begin{array}{c}\text { Treatment } \\
(\mu \mathrm{g} / \mathrm{ml})\end{array}$ & $\begin{array}{c}\text { Fluorescence } \\
(\mathrm{AU})\end{array}$ & $\begin{array}{c}\text { Relative } \\
\text { fluorescence }(\%)\end{array}$ & $<0.001$ \\
\hline 0.1 & $22671 \pm 441$ & $100.0 \pm 1.9$ & 20 & $16325 \pm 865$ & $72.0 \pm 3.8$ & $<0.001$ \\
0.2 & $24916 \pm 1009$ & $100.0 \pm 4.0$ & 40 & $16097 \pm 991$ & $64.6 \pm 4.0$ & $<0.001$ \\
\hline 0.4 & $27214 \pm 1390$ & $100.0 \pm 5.1$ & 80 & $15157 \pm 481$ & $55.7 \pm 1.8$ & $<$ \\
\hline
\end{tabular}

C. albicans cells treated with myricetin or an equivalent amount of DMSO were incubated in PBS containing $0.25 \mathrm{mg} / \mathrm{ml} \mathrm{Nile}$ red. The amount of Nile red binding to C. albicans cells was measured at $488 \mathrm{~nm}$ (bandwidth, $20 \mathrm{~nm}$ ) and $580 \mathrm{~nm}$ (bandwidth, $20 \mathrm{~nm}$ ), as the excitation and emission wavelengths, respectively, using a spectrofluorometer. The data represent the means \pm standard deviations obtained from one of three independent experiments. AU: arbitrary units.

binding of Nile red to cells would be changed if myricetin influences the lipid composition or organization of the cell membrane in C. albicans cells. As shown in Table 3, the relative binding of Nile red to myricetin-treated C. albicans cells was drastically reduced. After treatment with 20,40 , and $80 \mu \mathrm{g} / \mathrm{ml}$ myricetin for $1 \mathrm{~h}$, the relative percentages of Nile red binding to C. albicans cells were $72.0,64.6$, and $55.7 \%$, respectively, compared with the case for the corresponding DMSO-treated control cells. Consequently, a significant reduction of Nile red binding after myricetin treatment suggests that myricetin is induces alterations in the lipid composition or arrangement, such as the loosening of the packing of the lipid bilayer in cell membrane, leading to the enhanced membrane fluidity of C. albicans cells. Interestingly, treatment with 0.1 to $0.4 \%$ DMSO increased the fluorescence intensity of $C$. albicans cells (Table 3), since DMSO is a stain carrier that helps Nile red penetrate through the cell wall and cell membrane in microorganisms [45]. Nile red is also used to visualize and quantify lipid droplets, especially, droplets of neutral lipids within cells in oleaginous microorganisms such as Candida spp. [42,46]. Oleaginous yeasts can accumulate lipids in the range of 20 to $70 \%$ of their biomass under appropriate cultivation conditions [47]. Therefore, the reduced binding of Nile red to $C$. albicans cells does not indicate the only changes in membrane fluidity, but the significant reduction of the binding of both DPH and Nile red to myricetin-treated C. albicans cells suggests that myricetin induces changes in lipid components, such as ergosterol, phospholipids, or sphingolipids, in the cell membrane of myricetin-treated C. albicans cells. Thus, the enhanced membrane permeability and notable reduction of the entry of DPH into, and the binding of Nile red to, myricetin-treated C. albicans cells imply that myricetin increases membrane fluidity by inhibiting the biosynthetic pathways or functions of lipid components in the cell membrane, leading to perturbations in the structure and function of the cell membrane. To clarify this hypothesis, further studies will be needed. In conclusion, myricetin acts as an antifungal against C. albicans through a combined action of membrane disturbance by enhancing membrane permeability and cell wall damage. Thus, the presence of dual targets of myricetin against C. albicans indicates its potential as a therapeutic agent to treat infections caused by Candida spp.

\section{Acknowledgment}

This work was supported by the Sabbatical Research Grant 2019 of Semyung University.

\section{Conflict of Interest}

The authors have no financial conflicts of interest to declare.

\section{References}

1. Ruhnke M. 2006. Epidemiology of Candida albicans infections and role of non-Candida -albicans yeasts. Curr. Drug Targets 7: 495-504.

2. Deorukhkar SC, Saini S, Mathew S. 2014. Non-albicans Candida infection: an emerging threat. Interdiscip. Perspec.t Infect. Dis. 2014: 615958.

3. Odds FC, Gow NA, Brown AJ. 2001. Fungal virulence studies come of age. Genome Biol. 2: REVIEWS1009.

4. Lortholary O, Dupont B. 1997. Antifungal prophylaxis during neutropenia and immunodeficiency. Clin. Microbiol. Rev. 10: 477-504.

5. Calderone RA, Fonzi WA. 2001. Virulence factors of Candida albicans. Trends Microbiol. 9: 327-335.

6. Ramage G, Martínez JP, López-Ribot JL. 2006. Candida biofilms on implanted biomaterials: a clinically significant problem. FEMS Yeast Res. 6: 979-986.

7. Hitchcock CA, Dickinson K, Brown SB, Evans EG, Adams DJ. 1990. Interaction of azole antifungal antibiotics with cytochrome P450-dependent 14a-sterol demethylase purified from Candida albicans. Biochem. J. 266: 475-480.

8. Ghannoum MA, Rice LB. 1999. Antifungal agents: mode of action, mechanisms of resistance, and correlation of these mechanisms with bacterial resistance. Clin. Microbiol. Rev. 12: 501-517.

9. Gray KC, Palacios DS, Dailey I, Endo MM, Uno BE, Wilcock BC, et al. 2012. Amphotericin primarily kills yeast by simply binding ergosterol. Proc. Natl. Acad. Sci. USA 109: 2234-2239.

10. Anderson TM, Clay MC, Cioffi AG, Diaz KA, Hisao GS, Tuttle MD, et al. 2014. Amphotericin forms an extramembranous and fungicidal sterol sponge. Nat. Chem. Biol. 10: 400-406.

11. Hector RF. 1993. Compounds active against cell walls of medically important fungi. Clin. Microbiol. Rev. 6: 1-21.

12. Kurtz MB, Douglas CM. 1997. Lipopeptide inhibitors of fungal glucan synthase. J. Med. Vet. Mycol. 35: 79-86.

13. Vermes A, Guchelaar HJ, Dankert J. 2000. Flucytosine: a review of its pharmacology, clinical indications, pharmacokinetics, toxicity and drug interactions. J. Antimicrob. Chemother. 46: 171-179.

14. Carson CF, Mee BJ, Riley TV. 2002. Mechanism of action of Melaleuca alternifolia (tea tree) oil on Staphylococcus aureus determined by time-kill, lysis, leakage, and salt tolerance assays and electron microscopy. Antimicrob. Agents Chemother. 46: 1914-1920. 
15. Shapiro RS, Robbins N, Cowen LE. 2011. Regulatory circuitry governing fungal development, drug resistance, and disease. Microbiol. Mol. Biol. Rev. 75: 213-267.

16. Semwal DK, Semwal RB, Combrinck S, Viljoen A. 2016. Myricetin: A dietary molecule with diverse biological activities. Nutrients 8: 90 .

17. Jones JR, Lebar MD, Jinwal UK, Abisambra JF, Koren J 3rd, Blair L, et al. 2011. The diarylheptanoid (+)-aR,11S-myricanol and two flavones from bayberry (Myrica cerifera) destabilize the microtubule-associated protein tau. J. Nat. Prod. 74: 38-44.

18. Umadevi I, Daniel M, Sabnis SD. 1988. Chemotaxonomic studies on some members of Anacardiaceae. Proc. Plant Sci. 98: 205-208.

19. El-kader AMA, El-Readi MZ, Ahmed AS, Nafady AM, Wink M, Ibraheim ZZ. 2013. Polyphenols from aerial parts of Polygonum bellardii and their biological activities. Pharm. Biol. 51: 1026-1034.

20. Chua LS, Latiff NA, Lee SY, Lee CT, Sarmidi MR, Aziz RA. 2011. Flavonoids and phenolic acids from Labisia pumila (Kacip Fatimah). Food Chem. 127: 1186-1192.

21. Pekkarinen SS, Heinonen IM, Hopia AI. 1999. Flavonoids quercetin, myricetin, kaemferol and (+)-catechin as antioxidants in methyl linoleate. J. Sci. Food Agric. 79: 499-506.

22. Devi KP, Rajavel T, Habtemariam S, Nabavi SF, Nabavi SM. 2015. Molecular mechanisms underlying anticancer effects of myricetin. Life Sci. 142: 19-25.

23. Wang SJ, Tong Y, Lu S, Yang R, Liao X, Xu YF, et al. 2010. Anti-inflammatory activity of myricetin isolated from Myrica rubra Sieb. et Zucc. leaves. Planta Med. 76: 1492-1496.

24. Tong Y, Zhou XM, Wang SJ, Yang Y, Cao YL. 2009. Analgesic activity of myricetin isolated from Myrica rubra Sieb. et Zucc. leaves. Arch. Pharm. Res. 32: 527-533.

25. Salazar-Aranda R, Granados-Guzmán G, Pérez-Meseguer J, González GM, de Torres NW. 2015. Activity of polyphenolic compounds against Candida glabrata. Molecules 20: 17903-17912.

26. Maheshwari DT, Yogendra Kumar MS, Verma SK, Singh VK, Singh SN. 2011. Antioxidant and hepatoprotective activities of phenolic rich fraction of Seabuckthorn (Hippophae rhamnoides L.) leaves. Food Chem. Toxicol. 49: 2422-2428.

27. Clinical and Laboratory Standards Institute. 2008. M27-A3 Reference method for broth dilution antifungal susceptibility testing of yeasts: Approved standard. 3rd Ed. Clinical and Laboratory Standards Institute, Wayne, PA., USA.

28. Liu M, Seidel V, Katerere DR, Gray AI. 2007. Colorimetric broth microdilution method for the antifungal screening of plant extracts against yeast. Methods 42: 325-329.

29. Frost DJ, Brandt KD, Cugier D, Goldman R. 1995. A whole-cell Candida albicans assay for the detection of inhibitors towards fungal cell wall synthesis and assembly. J. Antibiot. 48: 306-310.

30. Lee HS, Kim Y. 2017. Paeonia lactiflora inhibits cell wall synthesis and triggers membrane depolarization in Candida albicans. J. Microbiol. Biotechnol. 27: 395-404.

31. Vaara M, Vaara T. 1981. Outer membrane permeability barrier disruption by polymixin in polymixin-susceptible and resistant Salmonella typhimurium. Antimicrob. Agents Chemother. 19: 578-583.

32. Lee HS, Kim Y. 2020. Aucklandia lappa causes membrane permeation of Candida albicans. J. Microbiol. Biotechnol. 30: 1827-1834.

33. Bradford MM. 1976. A rapid and sensitive method for the quantitation of microgram quantities of protein utilizing the principle of protein-dye binding. Anal. Biochem. 72: 248-254.

34. Rosenberg M, Azevedo NF, Ivask A. 2019. Propidium iodide staining underestimates viability of adherent bacterial cells. Sci. Rep. 9: 6483.

35. Bolard, J. 1986. How do the polyene macrolide antibiotics affect the cellular membrane properties? Biochim. Biophys. Acta 864: 257-304.

36. Gagoś M, Koper R, Gruszecki WI. 2001. Spectrophotometric analysis of organisation of dipalmitoylphosphatidylcholine bilayers containing the polyene antibiotic amphotericin B. Biochim. Biophys. Acta 1511: 90-98.

37. Gagoś M, Gabrielska J, Dalla Serra M, Gruszecki WI. 2005. Binding of antibiotic amphotericin B to lipid membranes: monomolecular layer technique and linear dichroism-FTIR studies. Mol. Membr. Biol. 22: 433-442.

38. Hoch HC, Galvani CD, Szarowski DH, Turner JN. 2005. Two new fluorescent dyes applicable for visualization of fungal cell walls. Mycologia 97: 580-588.

39. Demchenko AP, Mély Y, Duportail G, Klymchenko AS. 2009. Monitoring biophysical properties of lipid membranes by environment-sensitive fluorescent probes. Biophys. J. 96: 3461-3470.

40. Lee DS, Kim Y, Lee HS. 2017. The whcD gene of Corynebacterium glutamicum plays roles in cell division and envelope formation. Microbiology 163: 131-143.

41. Strahl H, Bürmann F, Hamoen LW. 2014. The actin homologue MreB organizes the bacterial cell membrane. Nat. Commun. 5: 1-11.

42. Greenspan P, Fowler SD. 1985. Spectrofluorometric studies of the lipid probe, nile red. J. Lipid Res. 26: 781-789.

43. Wasif Baig M, Pederzoli M, Jurkiewicz P, Cwiklik L, Pittner J. 2018. Orientation of laurdan in phospholipid bilayers influences its fluorescence: quantum mechanics and classical molecular dynamics study. Molecules 23: 1707.

44. Gao F, Mei E, Lim M, Hochstrasser RM. 2006. Probing lipid vesicles by bimolecular association and dissociation trajectories of single molecules. J. Am. Chem. Soc. 128: 4814-4822.

45. Chen W, Zhang C, Song L, Sommerfeld M, Hu Q. 2009. A high throughput Nile red method for quantitative measurement of neutral lipids in microalgae. J. Microbiol. Methods 77: 41-47.

46. Ramírez-Castrillón M, Jaramillo-Garcia VP, Lopes Barros H, Pegas Henriques JA, Stefani V, Valente P. 2021. Nile red incubation time before reading fluorescence greatly influences the yeast neutral lipids quantification. Front. Microbiol. 12: 619313.

47. Poontawee R, Yongmanitchai W, Limtong S. 2017. Efficient oleaginous yeasts for lipid production from lignocellulosic sugars and effects of lignocellulose degradation compounds on growth and lipid production. Process Biochem. 53: 44-60. 